\title{
Learning through research: from teaching science to the sphere
} of nursing care ${ }^{a}$

\author{
Aprender pela pesquisa: do ensino da ciência ao campo assistencial da enfermagem \\ Aprendizaje a través de la investigación: desde la enseñanza de la ciencia al campo asistencial \\ de la enfermería
}

\author{
Ítalo Rodolfo Silva ${ }^{1}$ \\ Joséte Luzia Leite ${ }^{2}$ \\ Maria Auxiliadora Trevizan ${ }^{3}$ \\ Isabel Amélia Costa Mendes ${ }^{3}$ \\ Thiago Privado da Silva ${ }^{2}$ \\ Silvia Maria de Sá Basílio Lins²
}

1. Universidade Federal do Rio de Janeiro.

Campus Macaé, Macaé, RJ, Brazil.

2. Universidade Federal do Rio de Janeiro.

Rio de Janeiro, RJ, Brazil.

3. Universidade de São Paulo.

Ribeirão Preto, SP, Brazil.
Corresponding author:

Ítalo Rodolfo Silva.

E-mail: enf.italo@hotmail.com

Submitted on $11 / 06 / 2016$.

Accepted on 03/15/2017.

DOI: 10.1590/2177-9465-EAN-2016-0329

\begin{abstract}
Objective: To understand the connections established between the teaching of research in undergraduate school and reflections on the context of nursing care based on the meanings assigned by nurses and undergraduate nursing students. Method: Qualitative research, the theoretical and methodological frameworks of which were Complexity Theory and Grounded Theory. Sixteen nurses and nine undergraduate nursing students participated. Data were collected through semi-structured interviews. Results: The study revealed that aspects that structure and maintain the scientific practice of nurses are connected with the teaching of nursing in undergraduate school. The transversality of teaching of research and strategies adopted by professors influence this process. Conclusion: In the nursing field, learning through research requires strategies that contextualize research within the context of care delivery, so that students perceive science as an element that structures their profession. For that research should be a non-linear, transversal procedure that takes place over the course of the undergraduate program.
\end{abstract}

Keywords: Nursing; Science; Knowledge Management.

\section{Resumo}

Objetivo: Compreender as conexões entre o ensino da pesquisa na graduação e os reflexos no contexto assistencial da enfermagem, a partir dos significados atribuídos por enfermeiros e estudantes universitários de enfermagem. Método: Pesquisa qualitativa cujos referenciais teórico e metodológico foram, respectivamente, a Teoria da Complexidade e a Teoria Fundamentada nos Dados. Participaram 16 enfermeiros e nove graduandos em enfermagem. A técnica de coleta de dados foi a entrevista semiestruturada. Resultados: $O$ estudo revelou que pontos estruturantes e mantenedores da prática científica do enfermeiro apresentam conexões com o ensino da pesquisa na graduação. Nesse processo, influenciam a transversalidade do ensino da pesquisa e as estratégias adotadas pelos professores. Conclusão: Na enfermagem, o aprender pela pesquisa requer estratégias que contextualizem pesquisa com a realidade assistencial, de modo que o estudante perceba a ciência como elemento estruturante de sua profissão. Para tanto, a pesquisa deverá ser processual, não-linear, transversal no decurso da graduação.

Palavras-chave: Enfermagem; Ciência; Gestão do Conhecimento.

\section{Resumen}

Objetivo: Comprender las conexiones entre la enseñanza de la investigación en la graduación y sus impactos en el contexto asistencial de enfermería a partir de los significados atribuidos por enfermeras y estudiantes universitarios de enfermería. Método: Investigación cualitativa cuyos referenciales teórico y metodológico fueron, respectivamente, la Teoría de la Complejidad y la Teoría Fundamentada en Datos. Participaron 16 enfermeras y nueve estudiantes, con recolección de datos por entrevista semiestructurada. Resultados: Los puntos estructurales y mantenedores de la práctica científica del enfermero presentan conexiones con la enseñanza de la investigación a nivel universitario. Impactan la transversalidad de la enseñanza y las estrategias adoptadas por los profesores. Conclusión: En la enfermería, el aprendizaje mediante la investigación necesita estrategias que contextualicen investigación con realidad asistencial, para que los estudiantes perciban la ciencia como elemento estructurante de su profesión. Así, la investigación debe ser procesual, no linear, transversal en el curso de graduación.

Palabras clave: Enfermería; Ciencia; Gestión del Conocimiento. 


\section{INTRODUCTION}

Nursing faces challenges at a global level and, at the same time, such challenges depend on the context in which nursing occurs. These challenges are linked to the demands from the knowledge-community on the economy of knowledge, the science fields of which, innovation and technology, are conditions that ground and consolidate a profession. ${ }^{1,2}$ It is, however, important to highlight the position of nursing in the scientific field, though nursing is seen as a science under construction, which has required efforts to achieve the status of a consolidated science. $^{3}$

To advance in the sciences and obtain social valorization, nurses have developed competencies that adjust to the contemporary needs of health systems, among which are the scientific empowerment to ground practice. ${ }^{4,5}$ Nonetheless, because these are complex systems, they are permeated with dynamic movements of evolution, which, in principle, sustain the importance of the teaching of science during formal education. ${ }^{6}$

In this context, the teaching system for the development of science requires abilities to adapt to humankind's global challenges in order to enable linking strategies that favor connecting the results of research to work processes. In nursing, the first challenge faced when attempting to establish such connections may be the nurses' lack of ability to see research as what grounds care delivery, which reinforces the need to focus on undergraduate programs as a valuable context for promoting a scientific spirit. ${ }^{7}$

Therefore, one has to consider not only the advancements nursing has achieved in research, but also and mainly its impact on the training process, that is, learning through research impacts the practice of nurses when delivering care. Despite scientific progress, ${ }^{8}$ the teaching of research in undergraduate schools presents important challenges, from teaching strategies adopted by professors, to the semester and quality of research content provided during the program. , $^{10}$

Note, however, that these challenges are not exclusive to the nursing field, ${ }^{11}$ nor are they health-related,,${ }^{12}$ or restricted to the national sphere. ${ }^{13}$ The problems that permeate the teaching of research are global and of a multidimensional nature..$^{3,5}$

Therefore, one has to know the conditions for which and/ or strategies with which nurses are preparing themselves to deal with the dynamic systems of the health system and of the job market, which includes the abilities to create, innovate and socially engage based on scientific frameworks. ${ }^{14}$ Given this context, it is important to understand how nurses and undergraduate nursing students see the teaching of research, as well as the connections between research and nursing care, in addition to factors that influence this process. Therefore, the following objective was established: to understand the connections between the teaching of research provided during undergraduate study and reflections on the nursing care context, based on the meanings assigned by nurses and nursing undergraduate students.

\section{METHOD}

This is an explanatory research study with a qualitative approach, the theoretical and methodological frameworks of which were Complexity Theory ${ }^{15}$ and Grounded Theory (GT), respectively. GT is a method based on a set of analytical resources, which when systematically conducted, can generate an explanatory theoretical matrix of the phenomenon under study. ${ }^{16}$

The study participants composed three groups: clinical nurses, nurse researchers, and undergraduate nursing students. The inclusion criterion for clinical nurses was having professional experience in their current position of at least one year, while the exclusion criterion was currently attending a graduate program.

Inclusion criteria for the nurse researchers were: having a doctoral degree and being a member of a research group registered in $\mathrm{CNPq}$, whose lines of research were somehow related to the field of work of the nurses included in the first group. Researchers whose experience, as PhDs, in managing research was less than two years were excluded.

The inclusion criterion for the third group was currently being enrolled in the last year of the nursing undergraduate program, while those who were members of a research group, of any other profession, were excluded.

A total of 25 participants were included: 10 clinical nurses, six researchers, and nine undergraduate nursing students.

In regard to research settings, it is important to consider that, as a science under construction and social practice, nursing is practiced in different settings and there may be peculiarities in each of these settings in which research and care delivery converge. Additionally, in regard to fields of knowledge and interventions, we highlight one subgroup-adolescence-as a singular subgroup when compared to other phases of life, given the need for scientific constructs inherent to this time of life, considering that the conception of the existence of an intermediate period between childhood and adulthood is relatively recent.

Therefore, the study setting for the group composed of clinical nurses was a study center of a university hospital directed to adolescent health, located in the capital of Rio de Janeiro, Brazil. The activities developed in this center comprise primary, secondary and tertiary health care delivery recommended by the Brazilian Healthcare System (SUS). The setting for the nurse researchers was restricted to research groups listed in the Directory of Research Groups at CNPq (National Council for Scientific and Technological Development), linked to universities in Rio de Janeiro. The third setting was the nursing undergraduate program of a federal public university in Rio de Janeiro.

The participants' selection was based on Grounded Theory non-probabilistic theoretical sampling, which consists of maximizing opportunities to compare facts or incidents to determine how a category varies in terms of its properties and dimensions. ${ }^{16}$ Data collection ceased when theoretical saturation was achieved, that is, when the categories presented explanatory 
density adequate to answer to the problem and reach the object of research.

The clinical nurses and undergraduate students were selected by convenience, according to the snowball technique. The nurse researchers were identified by consulting the Lattes Platform, CNPq's Directory of Research Groups, using the strategies presented in the table 1.

After selecting the research groups, each researcher was invited to participate in the study using the E-mail addresses provided in their Lattes curriculum. Data were collected through semi-structured interviews held from October 2014 to March 2015. The interviews were individually conducted and digitally recorded in private rooms on the premises of the settings previously described. The nurse researchers were interviewed in the teaching institution with which the research group is affiliated.

Data analysis began with the coding process, which in grounded theory consists of a comparative analysis that takes place at three levels: open, axial and selective. ${ }^{16}$ In open coding, the concepts were identified by comparing properties and dimensions of data. In this stage, preliminary codes emerged based on the titles assigned to each incident, idea or event. These preliminary codes were then compared and then grouped into conceptual codes. ${ }^{16}$

In the axial coding, conceptual codes were grouped to form categories and subcategoies. ${ }^{16}$ In this stage, data that were separated in the open coding were regrouped to provide a deeper explanation of the phenomenon.

Selective coding consisted of comparing and analyzing categories and subcategories, an ongoing process, the objective of which is to develop categories, and integrate and refine the theoretical matrix in order to enable the central phenomenon to emerge. ${ }^{16}$

The categories were sorted according to the paradigmatic model, ${ }^{16}$ a scheme that reveals explanatory coherence among dimensions that underlies the study object. Its structure is based on the following components: phenomenon, causal conditions, intervenient conditions, context, action/interaction strategies, and consequences.

The results were validated by 10 judges, namely: nurse researchers linked to research groups registered in $\mathrm{CNPq}$, from different regions of Brazil, with expertise in adolescent health, and well-recognized experience in the management of research. For that, the same strategy described in table 1 was used in the regions of Brazil.

We selected researchers from research groups in each Brazilian macro-region, that is: south, southeast, north, northeast and mid-west. The last region was not included because the group selected did not respond to our contact efforts. The distribution of judges per region resulted in: three judges from the north, three from the northeast, one from the southeast and three from the south.

The following criteria were established to select the groups with which the judges were affiliated: analysis of the groups' human resources based on data presented by CNPq's Directory of Research Groups, as well of the judges' scientific production, especially, the judges' role in research projects as coordinators.

The material used for validation was composed of a booklet comprising two components: a summary of the study's results and a validation instrument, the parameters of analysis of which were: Goodness of fit criteria (ability of a conceptual model to adjust to the reality under study); Understanding (how easily are the meanings that the concepts express grasped) and Theoretical Generalization (ability of a conceptual model to be applied in contexts similar to that where the phenomenon under study emerged). ${ }^{16}$ The judges were supposed to expressly make their assessments choosing one of the following options: totally corresponds, partially corresponds, or does not correspond. Whatever the option chosen, answers needed to be justified.

In order to put judges and researchers in contact for the validation process, a room was available during the $18^{\text {th }}$ National Seminar of Nursing Research (SENPE), which took place in Fortaleza, CE, Brazil in June, 2015. The seminar's theme was "Nursing research: applicability, implications and visibility". The judges who did not attend the seminar sent their analyses by mail directly to the primary researcher.

This study was approved by the Institutional Review Boards at the Anna Nery Nursing School, Federal University of Rio de Janeiro (protocol No. 6665.516/CAAE: 30438114000005238 ) and at the Pedro Ernesto University Hospital from the State University of Rio de Janeiro (protocol No. 686.612). The researchers complied with Resolution 466/12, National Council of Health. Participants voluntarily consented and signed free and informed

Table 1. Parameterized query to select research groups.

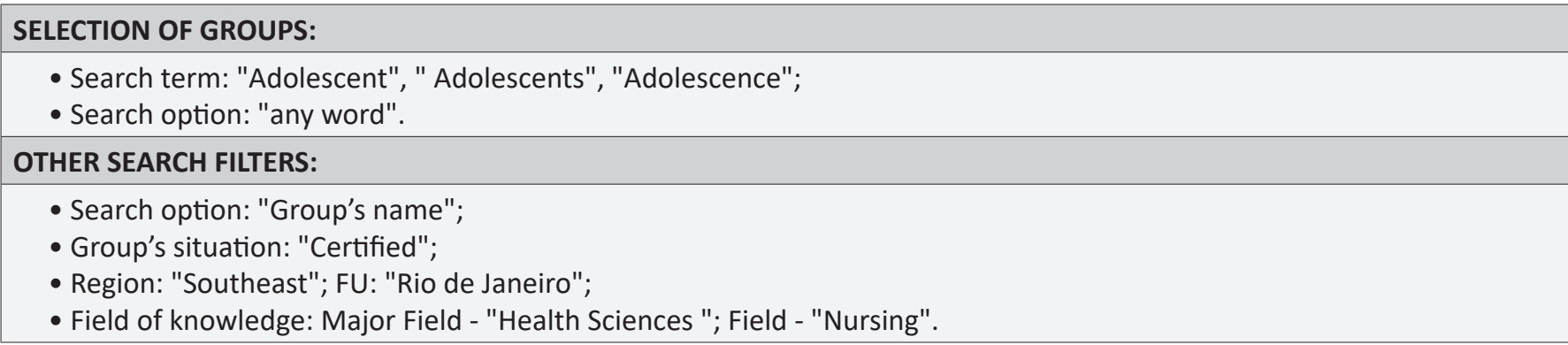

Source: Current database of Directory of Research Groups, National Council for Scientific and Technological Development - CNPq, Brazil (2015). 
consent forms. To preserve confidentiality of the participants' identities, they are identified alphanumerically, according to the group of origin and sequence in which the interviews occurred. Hence, first group (CN number: Clinical Nurses); second group (NR number: Nurse Researchers); and third group (US number: Undergraduate Students).

\section{RESULTS}

The clinical nurses had an average experience of four years and eight months; six out of the 10 were specialists, four of whom were specialists in adolescent health; two were members of research groups; four graduated from private schools, while six graduated from public schools.

All the nurse researchers were affiliated with public universities and had an experience of 24 years and six months, on average; all acquired a doctoral degree in the nursing field, eight years ago on average. Five were members in more than one research group; three were the leaders of these groups.

Among the undergraduate students, seven were members of research groups, six of which were scientific initiation grantees. None of the participants had attended any other undergraduate program in another subject.

This study's results derive from the theoretical matrix supported on the doctoral dissertation entitled "Gestão do Conhecimento Científico: conexões entre a pesquisa e o gerenciamento do cuidado de enfermagem no contexto da adolescência" [Management of Scientific Knowledge: connections between research and the management of nursing care in the context of adolescence]. In the paradigmatic model, because of theoretical density, the category that configures an intervenient condition of the phenomenon investigated in the dissertation is addressed here, that is: the teaching of science and connections between research and nursing care. The objective of the dissertation is to address the training process of nurses as a component that directly influences these connections. Therefore, the category presented is "From teaching science to the sphere of nursing care," grounded on three subcategories, the first of which is presented below.

\section{The teaching of research in undergraduate school and the flourishing of scientific practice}

The nurses' scientific practice is linked to encouragement received, already in the undergraduate program, to do research. In this context, competencies should be developed from the perspective of process, that is, initiated with the identification of each student's particular situation, and then proceed with a set of strategies that favors the emergence and/or improvement of skills and knowledge that take place with learning through research.

You take a student from high school and put him into the university. He gets there and needs to learn how to read a scientific paper [...] Then, in the field, he develops the ability to observe, to look at things in that place; he records what there is there, then thinks about what he's seen. He has to describe what he sees and then we put the parts together (NR3)

When we are encouraged to do research, it becomes easier to understand the importance of it for our professional future [...] we face obstacles in the beginning but, gradually, we manage to advance (US7).

Everything is stimulus; you start the practice in the undergraduate program. You won't be able to do it, like from out of the blue, but during the undergraduate program you start to learn and bring it into your practice, because when you get here things are much more complicated (CN1).

Aspects related to the institutions where these professionals graduated and whether research was taught over the course of the undergraduate program were highlighted to take into account the diverse contexts in which these nurses received training, considering possibilities and/or limitations imposed on the teaching of research. There is no consensus as to whether the context of public universities differs from the context of private universities in terms of the development of competencies for research.

Those who graduate in public schools, which have a stronger extension and research structure, enjoy easier access to this kind of information and tend to reproduce it as professionals (CN5).

I don't think it's only in public schools because I see my colleagues who graduated from private schools and know how to do research, but I guess it depends where you graduated from (CN7).

[...] in regard to the process of incorporating new knowledge, being literate in scientific knowledge of the field, I don't know if there's a problem whether it's public or private. I've never discussed whether public schools are better than private schools (NR2).

Among the elements that reinforce divergences between research and clinical practice is the fragmentation of the teaching of research during undergraduate programs. From this context, the following subcategory emerged.

\section{Challenges imposed on the establishment of a scientific spirit.}

The format through which research is taught during undergraduate programs was highlighted. In the perception of the undergraduate students and nurse researchers, a transversal type of teaching in which research is problematized, is necessary to establishing connections between research and the practice of nurses. Reinforcing this view, the clinical nurses considered that teaching isolated from research leaves the nursing work out of the context, as the following excerpts show. 
We have contact with research from the beginning of college. At the beginning, I confess that I didn't understand how to do it, could not see its importance (...) To my surprise, the Final Paper was a complication, but over the years, I naturally learned it and enjoyed doing it. All these helped me see research as something necessary for nursing, even in the delivery of care (US8).

If a student learns to consume knowledge, he learns to read a scientific paper; it changes the configuration (NR4).

Research in the field of nursing should be introduced from the beginning of the undergraduate program. Sometimes, research is relegated to the final half of the program and it hinders understanding of the relationship between research and nursing work (CN4).

The results emphasize the context of the undergraduate program as being where connections, between research and nursing care, are initially woven. At the same time, undergraduate students face incoherencies in this process.

Of most professionals I worked with, few showed a practice based on scientific evidence (US5).

Some studies we base our work on do not always portray the context of our practice, so we aren't able to incorporate this research into our practice because it's from another universe (US6).

Data show that the main mechanism attracting undergraduate nursing students and that keeps them focused on the voluntary development of research is the financial support provided by scientific initiation grants.

I've seen various classmates who developed their final paper based on research they started in the first semester of the program and, afterwards, it no longer had anything to do with them, but they remained because of the scholarship (US4).

Most are driven by the scholarship, sometimes they really find themselves and enjoy it, but other times they don't (US6).

People volunteer to participate in research but their first question is: is there a scholarship? If you say there is, people go but if you say no, it's not the same thing (US3).

This connection seems to be replicated by nurses when the search for professional improvement based on research is exclusively driven by the possibility of financial improvement, as illustrated by the following excerpt:

I see it a lot - nurses seek a Master's degree because of these interests I mentioned, especially because they are close to retirement and want a Master's to earn a bit more. I see this interest is not to improve their practice but is only restricted to financial improvement (NR1).

Some seek a Master's or doctoral degree because of the salary (NR6).

Incoherencies presented in the teaching of research in nursing may lead to frustration, devaluation, and resistance on the part of the professionals toward the consumption of scientific results in regard to incorporating them into their professional practice or to developing their own research. Such problems show the existence of epistemological obstacles potentially weakening the nurses' scientific praxis.

In this context, demotivation/devaluation and resistance that nurses face when incorporating the results of research into their care practice may be rooted in their initial experiences with research during college. Hence, strategies are needed to change this situation. Nonetheless, undergraduate professors and especially the final paper's advisor have a preponderant role in effectively introducing students to research. Based on this evidence, the third subcategory emerged.

\section{Reforming thought to think about the teaching of research in the undergraduate nursing program: the role of professors/advisors}

The role of the final paper's advisor when teaching research emerged as a facilitating element and, therefore, a valuable element in the initial experience of future nurses in the research process.

I've learned a lot from research. We mature, especially when your advisor is someone who gives you autonomy to do things. I guess it makes us grow, makes us more responsible (US7).

In college, I wanted to do my final paper on a given subject [...] but my advisor clipped my "wings" with many justifications [...] I ended up working on a different subject, but I didn't want to, I did it because I had to (CN2).

[...] what do we want? Is it research as part of the training process or the opportunity of training to do research? (NR4).

Similar to the advisor, the professor exerts significant influence on nursing students, gearing them toward understanding, valuing and encouraging the research process.

[...] you can tell the professors bring updated scientific concepts to class; we are encouraged to seek and study scientific papers (US3).

I guess they should show us the product and then show us how you do research. It'd be more interesting, more encouraging (US5). 
The previous discussion shows that undergraduate students reveal the importance of the professor using teaching and organizational strategies and the educational system to ease recognition of the connection between teaching of research and its rationale. In this sense, it is desirable to reinforce the evidence of the applicability of research into the nurses' practice.

\section{DISCUSSION}

The need to strengthen connections between the teaching of research and nursing care coincides with the fragmented process observed between training and practice, which dissociates scientific movement from its social relevance, hindering the development of science with awareness. ${ }^{15}$

In this vein, the university has tolerated deviations that contribute to the pathology of knowledge, by allowing training to be fragmented between the content and the context such content is supposed to portray. ${ }^{15}$ On the other hand, the results show how important it is that research-based education be transversally implemented during undergraduate studies, problematizing and contextualizing teaching in order to allow students to connect theory/research to practice. ${ }^{10,13}$ Additionally, transversal teaching of research allows for a rupture of the paradigm in which the final paper is a one-time, isolated task; rather, it is a strategy with the potential to facilitate student understanding of the scientific bases that support the profession. ${ }^{6,17}$

The foundation provided during the undergraduate program, that is, learning through research, consuming scientific products and/or developing research, favors the formation of nurses who are able to manage knowledge, ${ }^{4,18}$ and perhaps, break paradigms that place nursing on the periphery of the fields of science, innovation and technology.

The pathology of knowledge, the fragmentation of content, is very frequent, ${ }^{15}$ and is aggravated by recurrent linear thinking that takes place in the teaching of research, ${ }^{17}$ which is no different in the context of undergraduate nursing. In addition to the repercussions already mentioned, the fragmentation of knowledge makes it difficult for students and nurses to think and be entrepreneurs and develop patents. ${ }^{4,5,19}$

Therefore, we believe that the connections between research and nurses' care practices can reflect their training processes, especially in terms of the development of a scientific spirit, which is encouraged by a non-linear approach to the teaching of research. For this reason, this phenomenon is analogous to the dynamics of fractals, $20: 601$ namely: geometric structures, the pattern of which is replicated indefinitely in diverse scales, "generating complex figures that preserve in each of its parts the characteristics of the whole."

Self-similarity among the elements that constitute social phenomena, however, do not have the same fractal logic of physical and biological artifacts, which are subject to geometric mathematization because they belong to the same system. Each instance of a social phenomenon may suffer variations in a way that these phenomena may preserve similarities between the parts and the whole, but also present singular aspects that are subject to change. ${ }^{15}$ For this reason, social phenomena present potentially fractal dynamics.

The fractal dynamics is evidenced in this study's results through two examples: the first accrues from the movement of undergraduate students toward research, the primary motivation of which is financial aid provided by a scientific initiation grant. This pattern may repeat itself when nurses seek Master's or doctoral programs exclusively due to a financial motivation. This rationale is also a concern considering the social responsibility of science. ${ }^{6}$

Another case of potentially fractal dynamics seems to be the epistemological obstacle of the first experience ${ }^{7}$ that is, if the first experience of undergraduates with research takes place in an isolated/pathologized context, ${ }^{15}$ they may become frustrated; understand the research process as something dissociated from reality; and feel discouraged and uninterested in consuming and/or developing research. Consequently, this point of view may be projected into the work process when these students become nurses.

Additionally, the initial experience is reinforced by the influences exerted by professors and advisors, as they may positively or negatively impact the way future nurses will conceive of research and how important they will consider research for their work processes. The training of professors based on science is a condition for students to learn how to produce knowledge, and consequently, to consume research. ${ }^{6}$

Nonetheless, undergraduate professors are mistaken when they think that, because they are not teaching in a graduate program, they are not supposed to develop research, abstaining from authorship of the very knowledge they disseminate; that is, professors with poor training in research cannot teach students well. ${ }^{6}$

The process of scientific supervision, characterized as a step in the process of teaching through research, should be guided primarily by training/education based on scientific models that pertain to the work process. For that, it is desirable that professors/advisors understand the dimension they occupy in this system of human resources training in order to develop competencies in students so they can master the investigative process of nursing science and research policies. ${ }^{6,18}$

Teaching through research has important implications for both advisors and scientific initiation grantees; that is, it can motivate and improve the performance of future nurses' scientific practices, ${ }^{6,18,21}$ enabling them to understand the importance of science as the foundation of their professional practice, and possibly, to perceive themselves as future consumers of research. ${ }^{9,18}$ It is, however, important to emphasize that this scientific supervision should not be restricted to those receiving a scientific initiation grant.

The results also reveal the necessity of a discussion concerning differences in the teaching of research promoted in 
undergraduate nursing programs of public and private schools. There are controversies related to the capitalism of the market of teaching systems, especially in regard to the quality of teaching provided. ${ }^{21,22}$ Private schools, however, have been successful in the field of scientific research, both in Brazil ${ }^{23}$ and in other countries. ${ }^{24}$ Hence, simplifying the challenges posed to teaching through research based on whether it is a public or private school, disregarding the context, will possibly neglect the phenomenon itself, which, in principle, is a complex problem that also affects public universities. ${ }^{6}$

Taking these challenges as priorities for the development of human capital, starting with undergraduate sphere, implies promoting the quality of different factors that influence nursing work, especially one's critical-reflective ability to make sciencebased decisions; ${ }^{25-27}$ competencies to require research that solve work process related problems or that reorient work processes; ${ }^{2}$ the ability to understand the nursing process as a problem-solving scientific method; the initiative to train nurses to adhere to the health systems and care delivery.

\section{CONCLUSIONS}

The results show that nursing undergraduate programs can either enhance or inhibit nurses' future interactions of research and practice. In the meantime, the success of teaching research, as a multifaceted phenomenon, is impacted by factors such as: the training context; undergraduate professors; and final paper advisors, which, in the condition of intervenient factors, can either strengthen or weaken the students' relationship with research, the relationship of research with reality, and perhaps, that of research with care delivery.

In fact, strategies that contextualize research within the objective reality of nursing care were highlighted: students need to perceive science as the being the foundation of their training and professional practice. It appears that these connections enable students to value research beyond the financial incentive provided by scientific initiation grants or scholarships. For that, the teaching of research should be a non-linear transversal procedure taking place over the undergraduate program.

It is important to note that this study presents some limitations, such as the context from which the results emerge, considering that the public context of teaching and professional practice may reveal facets that differ from those in the private context, especially because most undergraduate students in public schools receive scientific initiation grants. Therefore, further studies are needed to deepen the analysis of this phenomenon, as well as to bring out dimensions that were not addressed in this study, with a view to strengthen mechanisms to intervene in the connections between research and nursing care.

Finally, even though adolescent health was a common ground among the participants' practice and research settings, the study's results did not present any restrictions on this context as being either favorable or unfavorable to undergraduate teaching, nor for the connections between research and nursing care.

\section{ACKNOWLEDGMENTS}

Special thanks to Commander Dr. Leila Milman Alcantara (in memoriam) for having encouraged the development of this study.

\section{REFERENCES}

1. Kahn M. A cooperação dos BRICS na ciência, tecnologia e inovação: retórica e realidades. Contexto Int [Internet]. 2015; [cited 2016 Jun 20]; 37(1):185-2013. Available from: http://www.scielo.br/scielo. php?pid=S0102-85292015000100185\&script=sci_abstract\&tlng=pt http://dx.doi.org/10.1590/S0102-85292015000100006

2. Schveitzer MC, Backes VMS, Prado ML, Lino MM, Ferraz F. Grupos de pesquisa em educação em enfermagem: linhas de pesquisa e produção científica em três regiões do Brasil. Rev Bras Enferm [Internet]. 2012 Mar/ Apr; [cited 2015 Sep 12]; 65(2):332-8. Available from: http://www.scielo. br/scielo.php?script=sci_arttext\&pid=S0034-71672012000200020\&In $\mathrm{g}=e n \& \mathrm{nrm}=$ iso. $\mathrm{http}: / /$ dx.doi.org/10.1590/S0034-71672012000200020

3. Carvalho V. Sobre os constructos epistemológicos nas ciências uma contribuição para a enfermagem. In: Carvalho V, org. Para uma epistemologia da enfermagem: tópicos de crítica e contribuição. Rio de Janeiro: UFRJ/EEAN; 2013. p. 259-79.

4. Backes DS, Grando MK, Gracioli MSA, Pereira ADA, Colomé JS, Gehlen LH. Vivência teórico-prática inovadora no ensino de enfermagem. Esc Anna Nery [Internet]. 2012 Sep; [cited 2015 Jan 18]; 16(3):597-602. Available from: http://www.scielo.br/scielo.php?script=sci_arttext\&p $\mathrm{id}=$ S1414-81452012000300024. http://dx.doi.org/10.1590/S1414 81452012000300024

5. Koerich MHAL, Vieira RHG, Silva DE, Erdmann AL, Meirelles BHS Produção tecnológica Brasileira na área de enfermagem: avanços e desafios. Rev Gaúcha Enferm [Internet]. 2011 Dec; [cited 2014 Feb 12];32(4):736-46. Available from: http://www.scielo.br/scielo. php?script=sci_arttext\&pid=S1983-14472011000400014\&Ing=en\&nr m=iso. http://dx.doi.org/10.1590/S1983-14472011000400014

6. Demo P. Aprender como autor. São Paulo: Atlas; 2015. 208 p.

7. Bachelard G. A formação do espírito científico: contribuição para uma psicanálise do conhecimento. Rio de Janeiro: Contraponto; 1996. 316 p.

8. Scochi CGS, Munari DB, Gelbcke FL, Ferreira MA. The challenges and strategies from graduate programs innursing for the dissemination of scientific production at international journals. Esc Anna Nery [Internet] 2014 Jan/Mar; [cited 2015 Jun 2]; 18(1):5-6. Available from: http://www. scielo.br/scielo.php?pid=S1414-81452014000100005\&script=sci_ arttext\&tlng=en. http://dx.doi.org/10.5935/1414-8145.20140001

9. Piexak DR, Balem JGT, Silveira RS, Fernandes GFM, Lunardi VL, Backes DE. A percepção de estudantes da primeira série de um curso de graduação em enfermagem acerca da pesquisa. Esc Anna Nery [Internet]. 2013 Jan/Mar; [cited 2014 Nov 8]; 17(1):68-72. Available from: http://www.scielo. br/scielo.php?script=sci_arttext\&pid=S1414-81452013000100010\&lng= en\&nrm=iso. $\mathrm{http}: / / d x . d o i . o r g / 10.1590 / S 1414-81452013000100010$

10. Pires AS, Souza NVDO, Penna LHG, Tavares KFA, D'oliveira CAFB, Almeida $\mathrm{CM}$. The nursing training at the undergraduate: a integrative literature review. Rev Enferm UERJ [Internet]. 2014; [cited 2014 Jun 21]; 22(5):705-11. Available from: http://www.e-publicacoes.uerj.br/ index.php/enfermagemuerj/article/view/11206/12314. http://dx.doi org/10.12957/reuerj.2014.11206

11. Maltagliati LV, Goldenberg P. O lugar da pesquisa na reorganização curricular em odontologia: desafios de origem para um debate atual. Saúde Soc [Internet]. 2011 Apr/Jun; [cited 2014 Sep 23]; 20(2):43646. Available from: http://www.scielo.br/scielo.php?script=sci arttext\&pid=S0104-12902011000200015\&Ing=en\&nrm=iso. http:// dx.doi.org/10.1590/S0104-12902011000200015

12. Tassigny MM, Brasil MVO. Pesquisa na graduação de administração: mediação necessária ao processo ensino-aprendizagem. Rev GUAL [Internet]. 2012 Aug; [cited 2015 May 7]; 5(2):158-73. Available from: https://periodicos.ufsc.br/index.php/gual/article/ view/1983-4535.2012v5n2p158. http://dx.doi.org/10.5007/19834535.2012v5n2p158 
13. Mick J. Nurse interns' experience with participation in the evidencebasead pratice project requirement of a nursing internship Program. Nurse Educ [Internet]. 2014 Mar/Apr; [cited 2015 Mar 28]; 39(2):54-5. Available from: http://www.nursingcenter.com/journalarticle?Article_ ID $=1699303$

14. Almeida RC, Chaves M. Empreendedorismo como escopo de diretrizes políticas da União Europeia no âmbito do ensino superior. Educ Pesqui [Internet]. 2015; [cited 2015 Sep 28]; 41(2):51326. Available from: http://www.scielo.br/scielo. php?pid=S151797022015000200513\&script=sci_abstract\&tlng=pt. http://dx.doi. org/10.1590/S1517-97022015041779

15. Morin E. Ciência com consciência. $13^{\underline{a}}$ ed. Rio de Janeiro: Betrand; 2010. $350 \mathrm{p}$.

16. Strauss AL, Corbin J. Pesquisa qualitativa: técnicas e procedimentos para o desenvolvimento de teoria fundamentada. $2^{\mathrm{a}} \mathrm{ed}$. Porto Alegre: Artmed; 2008. $288 \mathrm{p}$.

17. Demo P. Olhar do educador e novas tecnologias. Bol Téc Senac [Internet]. 2011 Mai/Aug; [cited 2014 Aug 5]; 37(2):15-25. Available from http://www.bts.senac.br/index.php/bts/article/view/190

18. Erdmann AL, Leite JL, Nascimento KC, Lanzoni GMM. Vislumbrando a iniciação científica a partir das orientadoras de bolsistas da Enfermagem. Rev Bras Enferm [Internet]. 2011 Mar/Apr; [cited 2015 Jun 20]; 64(2):261-7. Available from: http://www.scielo.br/pdf/reben/v64n2/ a07v64n2.pdf. http://dx.doi.org/10.1590/S0034-71672011000200007

19. Andrade AC, Dal Ben LW, Sanna MC. Entrepreneurship in nursing: overview of companies in the state of São Paulo. Rev Bras Enferm [Internet]. 2015 Jan/Feb; [cited 2015 Sep 14]; 68(1):40-4. Available from: http://www.scielo.br/pdf/reben/v68n1/en_00347167-reben-68-01-0040.pdf. http://dx.doi.org/10.1590/00347167.2015680106p

20. Tôrres JJM, Góis CWL. Organização fractal: um modelo e sugestões para gestão. Rev Ciênc Admin [Internet]. 2011 Sep/Dec; [cited 2015 Jul 10]; 17(3):593-620. Available from: https://www.unifor.br/images/ pdfs/cca/v17_n3_artig01.pdf
21. Rocha EMOR, Nunes BMVT. Expansão dos cursos de graduação em enfermagem: estudo no Piauí. Rev Bras Enferm [Internet]. 2013 May/ Jun; [cited 2014 Sep 2]; 66(3):391-98. Available from: $\mathrm{http}: / /$ www.scielo. br/scielo.php?script=sci_arttext\&pid=S0034-71672013000300014. http://dx.doi.org/10.1590/S0034-71672013000300014

22. Tavares MA. Trabalho docente na universidade pública: uma reflexão sobre o produtivismo acadêmico na contemporaneidade. Argumentum [Internet]. 2011 Jun/Jul; [cited 2015 Aug 5];3(1):238-50. Available from: http://periodicos.ufes.br/argumentum/article/view/1175/1044

23. Féres-Carneiro T. Departamento de Psicologia da PUC-Rio: 60 anos de formação e produção de conhecimento. Psicol Clin [Internet]. 2013 Jan/ Jun; [cited 2015 Aug 5]; 25(2):233-46. Available from: http://www.scielo. br/scielo.php?script=sci_arttext\&pid=S0103-56652013000200014 http://dx.doi.org/10.1590/S0103-56652013000200014

24. Christensen $\mathrm{CM}$, Eyring HJ. The Innovative University: Changing the DNA of Higher Education From the Inside Out. San Francisco: JosseyBass; $2011.512 \mathrm{p}$.

25. Freitas PH, Colomé JS, Carpes AD, Backes DS, Beck CLC Repercussions of the program for education through work for health (pet-health) in the training of students from the health area. Esc Anna Nery [Internet]. 2013 Jul/Aug; [cited 2015 Aug 5]; 17(3):496504. Available from: http://www.scielo.br/scielo.php?pid=S1414$81452013000300496 \&$ script=sci_arttext\&tlng=en. http://dx.doi. org/10.1590/S1414-81452013000300013

26. Peterson MH, Barnason S, Donnelly B, Hill K, Milley H, Riggs L, et al. Choosing the best evidence to guide clinical practice: application of AACN levels of evidence. Crit Care Nurse. [Internet]. 2014 Apr; [cited 2015 Aug 5]; 34(2):58-68. Available from: http://ccn.aacnjournals.org/ content/34/2/58.long. http://dx.doi.org/10.4037/ccn2014411

27. Stein KF. Research: an essential (but perhaps underutilized) component to effective psychiatric mental health nursing practice. J Am Psychiatr Nusses Assoc. [Internet]. 2014 Jan/Feb; [cited 2015 Aug 5]; 20(1):29-30. Available from: http://journals. sagepub.com/doi/pdf/10.1177/1078390313520134. http://dx.doi. org/10.1177/1078390313520134

\footnotetext{
a Paper derived from the Doctoral Dissertation "Gestão do conhecimento científico: conexões entre a pesquisa e o gerenciamento do cuidado de enfermagem no contexto da adolescência." [Management of Scientific Knowledge: connections between research and the management of nursing care in the context of adolescence] presented to the Nursing Undergraduate Program at Anna Nery Nursing School/UFRJ.
} 